\title{
Graduate Students' Knowledge about Plagiarism in Academic Writing
}

\author{
Najmi Rodhiya ${ }^{1}$, Primardiana Hermilia Wijayati ${ }^{2}$, Herri Akhmad Bukhori ${ }^{2}$ \\ ${ }^{1}$ Keguruan Bahasa-Universitas Negeri Malang \\ ${ }^{2}$ Pendidikan Bahasa Jerman-Universitas Negeri Malang
}

\section{INFO ARTIKEL}

\section{Riwayat Artikel:}

Diterima: 04-07-2020

Disetujui: 19-02-2020

Kata kunci:
graduate student;
plagiarism;
academic writing;
mahasiswa pascasarjana;
plagiat;
penulisan akademik

\section{Alamat Korespondensi:}

Najmi Rodhiya

Keguruan Bahasa

Universitas Negeri Malang

Jalan Semarang 5 Malang

E-mail: nazmirodhiya11@gmail.com

\section{ABSTRAK}

Abstract: Plagiarism is one of academic dishonesty, which has become a central issue in the academic sector. The aims of this study were to investigate students understanding through plagiarism and also to examine the reason why they committed plagiarism. This study used a quantitative approach. To obtain the data, questionnaire and interview were used. The finding showed that their understanding of plagiarism bounded in citing without giving sources. Further, the result showed that lack of knowledge, lack of time and unintentionally committed plagiarism were the top three reasons why the graduate students committed plagiarism.

\begin{abstract}
Abstrak: Plagiasi adalah salah satu ketidakjujuran akademik yang menjadi isu utama dalam bidang akademik.Tujuan penelitian ini adalah untuk menyelidiki pemahaman siswa tentang plagiasi dan untuk mengetahui alasan mengapa mereka melakukan tindakan plagiasi. Penelitian ini menggunakan pendekatan kuantitatif. Kuesioner dan wawancara digunakan untuk mengumpulkan data. Hasil dari penelitian ini menunjukkan bahwa pemahaman mereka tentang plagiasi hanya terbatas tentang mengutip tanpa memberikan rujukan. Selanjutnya, hasilnya penelitian ini menunjukkan bahwa kurangnya pengetahuan, waktu dan kemudahan untuk menemukan materi di internet merupakan tiga alasan utama mengapa mahasiswa pascasarjana melakukan tindakan plagiasi.
\end{abstract}

Plagiarism is one of academic dishonesty which has become a central issue and challenges faced by the educational sector. The change of assessment method from oral examination to paper examination due to the increasing number of students made them easier to cheat and plagiarize (Gallant, 2011). Some studies revealed that plagiarism can be considered as a serious crime because it involves someone's ideas and creativity and it has been increased nowadays. Therefore, plagiarism is a serious problem faced by all of the level education including colleges and universities. Hornby (2010) defines plagiarism as the act of "taking the work or idea of someone else and pass it off as one's own". Ellis, Zucker \&Randall (2018) defined plagiarism as declaring someone else's words and/or ideas as own without appropriate attribution. Moreover, Sánchez-Vega Et al (2013) added Plagiarism as intellectual theft. From the definition above, it can be concluded that plagiarism is claiming someone's idea, thoughts, or inventions to be one's own without any attribution mentions to the original. On the other hand, some experts argued that plagiarism was complicated yet not impossible to define (Selemani, Chawinga, \& Dube, 2018). Then, Gullifer and Tyson (2014) conclude that there was no standard definition for plagiarism, as a result, each person has a different understanding of plagiarism.

It is needed to know and understand some rules in academic writing in order to prevent plagiarism (Salemani et al, 2018). Bailey (2011) stated that academic writing is a difficult task because it is including summarizing, paraphrasing, and quoting others' existing and prior ideas. When the writers do those actions (summarizing, paraphrasing and quoting), citing the source properly is needed and if they failed to do that, their writing can be considered as plagiarism. Furthermore, students and faculty sometimes have different perception about plagiarism (Kwong, et al., 2010). Institutions have to find ways to give accurate information about plagiarism so that plagiarism can be prevented. Based on Gonzalez (2017) ways to prevent plagiarism are help the students to identify plagiarism and give the students practice correctly in citing sources. Consequently, plagiarism in the education sector will be reduced and the students can improve their learning in research and writing skill. 
Many studies conducted in order to know how knowledgeable students and academic staff about plagiarism in academic writing. First, Ibegbulam \& Eze (2015) who examined about Nigerian students' knowledge, perceptions, and attitude to plagiarism. The result showed that the subject of this study had a low understanding of plagiarism because they never thought about how to avoid the plagiarism. Moreover, this study also classify plagiarism into two categories, unintentional and intentional. Unintentional plagiarism is plagiarism made by the student because of a lack of writing skill and does not know how to avoid it. In contrast, intentional plagiarism is committing plagiarism consciously and have a knowledge what constitutes plagiarism (Mahmood et al, 2010).

Moreover, Sarlauskiene \& Linas (2014) investigated students' understanding of plagiarism in HEIs of Lithuania. The subjects were 119 undergraduate students in HEIs of Lithuania. The purpose of this research was to identify the understanding of plagiarism by the students in HEIs of Lithuania. The students stated that they knew about plagiarism, but the result of the study showed that their understanding about plagiarism was still low. A clear definition and types of plagiarism can help the student prevent plagiarism. Then, Selemani, et al (2018) also investigated knowledge, reasons, and forms of plagiarism committed by the postgraduate students at Mzuzu University in Malawi. The result showed that postgraduate students had a conceptual understanding of plagiarism but they still committed plagiarism because of the pressure for a good grade, laziness and poor time management and lack of good academic writing. The most forms of plagiarism that ware committed by the postgraduate students due to lack of proper acknowledgment after paraphrasing, summarizing, and using quotation mark.

In committing plagiarism, there are various argumentations why the students committing that. Many studies had been conducted in order to reveal their reason for committing this academic misconduct. For example, Sikes (2009) believed that plagiarism happened because of the change in moral value on what constitutes plagiarism and pressure on publication in an academic setting. Moreover, Ahmadi (2014) argued that the internet also had a contribution to students to plagiarize. Other reasons which contribute in plagiarism such as students' laziness, lack of skill in academic writing and lack of education of plagiarism, deficiency in education systems in terms of assessment mode and inconsistencies in applying rules by academic staff (Batane, 2010; De Jager \& Brown, 2010). Therefore, many possibilities that can make the students committing plagiarism.

The writer found some existing gaps. The first gap is the level of education. The writer is interested in conducting the data about the knowledge of graduate students toward plagiarism. It is because most of the researcher took an interest in the area of undergraduate students while other researcher took postgraduate students as the subject of the research. However, the understanding of plagiarism is considered important to them since they also have to publish the article which one of the requirements is the originality. Besides, the different level of education may have an effect on the understanding of plagiarism. The second gap is most of the plagiarism issue is conducted in medical science and only a few of it in social science. When it conducted in social science, mostly the study conducted for EFL students (Sikes, 2009; Ahmadi, 2014). As a result, the writer interest to know how the knowledge of other language students. Then, the last gap is the existence of a plagiarism detection system. Based on the previous study, it can be concluded that the students had a low awareness of plagiarism because the university did not have a plagiarism detection system. However, this present research employs the students of the university, which have a plagiarism detection system. This study wants to explore whether the existence of plagiarism checker has a contribution to students' awareness of plagiarism.

Therefore, this present study is aimed at investigating graduate students in language major graduate knowledge about plagiarism in the Universitas Negeri Malang. Moreover, this study also wants to shed light on various reasons why they committed plagiarism. This finding was hoped revealing graduate students' understanding about plagiarism so that if there were a misconception among them, it could be fixed. Besides, this study is also expected to acknowledge the cause of why graduate students committing plagiarism, so that the plagiarism could be lessened in an academic context.

\section{METHOD}

This present study used a quantitative approach and survey as the research design. 86 graduate students took part in this present study and 12 of them were interviewed. The participant was from four language majors; Pendidikan Bahasa Indonesia, Pendidikan Bahasa Inggris, Pendidikan Bahasa Arab and Keguruan Bahasa in Universitas Negeri Malang. They were all selected based on their willingness and availability to participate in this present study.

Questionnaire and interview guideline were used to collect the data in this study. The questionnaire was used to find out graduate knowledge about plagiarism and why they committing it. Therefore, the questionnaire was divided into two parts. There are 10 questions for a questionnaire of graduate students' knowledge and 16 statements for questionnaire related to graduate students' reason why committing plagiarism. Those items had three options; Yes, Uncertain and No. For the reasons why graduate students plagiarized, the students could answer more than one statements. They were also asked to write down their own opinion if they thought their reason was not on the list. Both of the questionnaires were adapted from (Ibegbulam \& Eze, 2015) and (Lei \& Hu, 2015) for knowledge of plagiarism. While for questionnaire for the reason why graduate students committing plagiarism, the statements were adapted from Razera (2011).

The instruments were checked by one expert validator, who specialized in academic writing and plagiarism. The instruments were revised based on the feedback of the expert validator. Further, trying out the instruments was also carried out on 20 graduate students to check potential problems that might hinder respondents' comprehension and completion of the survey. To collect the data, the writers used direct procedure. It means that the writers directly gave the respondents the questionnaires. 
After that, the writer gave the respondents time to answer the questionnaire. Then, the writer analyzed the respondents' respond through the questionnaire and seek suitable respondents for interview. Further, for graduate students knowledge, the result will be described following three Likert Scale categories; Good, Fair and Bad with $\mathrm{P}=6$. The total of the highest score $=$ the highest score per item $X$ total questions $=3 \times 8=24$. Category 1 (scored $>=8-13$ ) indicated that they had a bad knowledge. Category 2 (scored $>=14-$ 19 ) indicated that they had fair knowledge and category 3 (score $>=20-24$ ) indicated that they had good knowledge.

Moreover, the interview was used to ask and get deeper information related to graduate students' knowledge, perception through plagiarism and the reason why they committing it. The questions regarding plagiarism were based around two main questions; In your opinion, what do you think plagiarism is? And In your opinion, what causes might students plagiarize?. The interview was done by the first writer and ranged in length around 10 minutes. The interview session was recorded and after that the writer transcribed it.

\section{FINDING}

The data obtained from this research were tabulated and presented quantitatively to see the students' knowledge about plagiarism and their reason behind it. The finding of this study is divided into two parts; the graduate student's knowledge of plagiarism and the reason why graduate students committed plagiarism.

\section{The Graduate Students Knowledge of Plagiarism}

Based on the questionnaire and the interview, it was found that the graduate students knowledge about plagiarism was good. It was proven by around $80 \%$ of students know and understand well of plagiarism terms and types. In contrast, only $9 \%$ of students had a bad knowledge of plagiarism. It means that around $9 \%$ of graduate students did not understand plagiarism well in term and types. Moreover, $11 \%$ of students had a fair knowledge of plagiarism. It means that they only partly know about plagiarism terms and types. The result of graduate students' knowledge about plagiarism can be seen in Table 1 and Figure 1 below.

Table 1. Graduate Students Knowledge about Plagiarism

\begin{tabular}{|c|c|c|c|c|c|c|c|}
\hline \multirow{2}{*}{ No } & \multirow{2}{*}{ Statement } & \multicolumn{2}{|c|}{ Yes } & \multicolumn{2}{|c|}{ Uncertain } & \multicolumn{2}{|r|}{ No } \\
\hline & & $\mathbf{F}$ & $\mathbf{P}$ & $\mathbf{F}$ & $\mathbf{P}$ & $\mathbf{F}$ & $\mathbf{P}$ \\
\hline 1. & Using others idea without citing the sources is a form of plagiarism. & 71 & $82,6 \%$ & 2 & $2,3 \%$ & 13 & $15,1 \%$ \\
\hline 2. & Using other ideas and claimed it as one's is a form of plagiarism. & 66 & $76,7 \%$ & 7 & $8,1 \%$ & 13 & $15,1 \%$ \\
\hline 3. & Using inaccurate sources is form of plagiarism & 44 & $51,2 \%$ & 26 & $30,2 \%$ & 16 & $18,6 \%$ \\
\hline 4. & Paraphrasing paragraph without citing the source is form of plagiarism & 48 & $55,8 \%$ & 28 & $32,6 \%$ & 10 & 11,6 \\
\hline 5. & $\begin{array}{l}\text { Copying paragraphs by making a few changes with words which have the same meaning } \\
\text { is a form of plagiarism. }\end{array}$ & 37 & $43 \%$ & 42 & $48,8 \%$ & 7 & $8,1 \%$ \\
\hline 6. & Citing sources written in other people works is a form of plagiarism. & 45 & $52,3 \%$ & 17 & $19,8 \%$ & 24 & $27,9 \%$ \\
\hline 7. & Using others work and claimed it as owns is a form of plagiarism. & 66 & $76,7 \%$ & 1 & $1,2 \%$ & 19 & $22,1 \%$ \\
\hline 8. & Copy paste from the internet without citing the source is a form of plagiarism. & 64 & $74,4 \%$ & 10 & $11,6 \%$ & 12 & $14 \%$ \\
\hline
\end{tabular}

Based on the table, it can be seen that most graduate students know several types of plagiarism. $82,6 \%$ of graduate students believe that using others idea without citing the sources is a form of plagiarism. Related with a form of plagiarism, 76,7\% and $74,4 \%$ of graduate students argue that using others idea and work claiming as own and copy paste from the internet without citing the source are a form of plagiarism respectively. It means that generally, graduate students familiar with those form of plagiarism.

However, 55,8\% and 52,3\% of graduate students believe that paraphrasing paragraph without citing the source and citing sources written in other people work is a form of plagiarism in succession. $51,2 \%$ of graduate students thought that using inaccurate sources is a form of plagiarism. It means that many graduate students unfamiliar with these form of plagiarism. Then, only $43 \%$ of graduate students believe that copying paragraphs by making a few changes with words which have the same meaning is a form of plagiarism. It means that many graduate students not knowing about this form as plagiarism.

Then, based on the table, it was found that there are three levels of the students, Good, Fair and Bad. The students with good knowledge about plagiarism are the students who got the total score range from 35 to 45 . The students with fair knowledge about plagiarism are the students who got the total score range from 25 to 34 . The students with a bad knowledge about plagiarism are the students who got the total score range from 15 to 24 . Students percentage of knowledge about plagiarism can be seen in the figure below. 


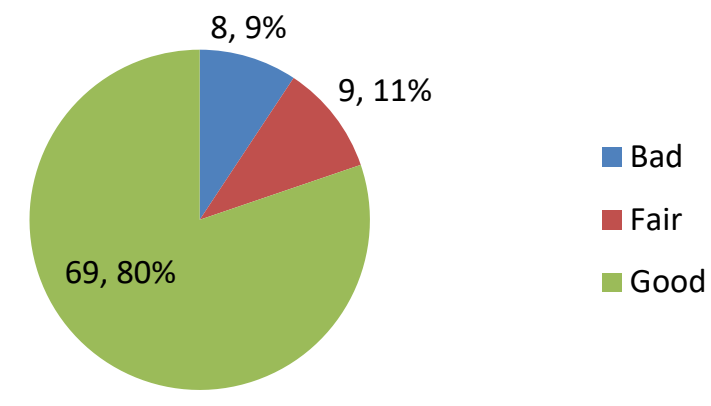

Figure. 1 Graduate Students' Percentage of Knowledge about Plagiarism

\section{Graduate Students' Reason why Committing Plagiarism}

Based on the questionnaire and the interview, it was found that every graduate students had their own reason why they committed plagiarism. However, most of them answered that a lack of understanding of plagiarism and lack of time to finish the task were their main reason why they committed plagiarism. The result of graduate students reasons why committing plagiarism based on the questionnaire can be seen in table 2 .

Table 2. Students ‘ Reason Why They Committing Plagiarism

\begin{tabular}{|c|c|c|c|c|c|c|c|}
\hline \multirow{2}{*}{ No } & \multirow{2}{*}{ Statement } & \multicolumn{2}{|c|}{ Yes } & \multicolumn{2}{|c|}{ Uncertain } & \multicolumn{2}{|c|}{ No } \\
\hline & & $\mathbf{F}$ & $\mathbf{P}$ & $\mathbf{F}$ & $\mathbf{p}$ & $\mathbf{F}$ & $\mathbf{P}$ \\
\hline 1. & Laziness & 21 & $24,4 \%$ & 19 & $22,1 \%$ & 46 & $53,5 \%$ \\
\hline 2. & Unintentionally & 27 & $31,4 \%$ & 32 & $37,2 \%$ & 27 & $31,4 \%$ \\
\hline 3. & Did not know plagiarism had many types & 30 & $34,9 \%$ & 25 & $29,1 \%$ & 31 & $36 \%$ \\
\hline 4. & Did not have time to do the task & 30 & $34,9 \%$ & 21 & $24,4 \%$ & 35 & $40,7 \%$ \\
\hline 5. & The time which given was limited & 25 & $29,1 \%$ & 19 & $22,1 \%$ & 42 & $48,8 \%$ \\
\hline 6. & To compete with friends & 3 & $3,5 \%$ & 13 & $15,1 \%$ & 70 & 81,4 \\
\hline 7. & Because my friends also do that. & 8 & $9,3 \%$ & 17 & $19,8 \%$ & 61 & $70,9 \%$ \\
\hline 8. & Get a higher score. & 3 & $3,5 \%$ & 14 & $16,3 \%$ & 69 & $80,2 \%$ \\
\hline 9. & Saving the time in complete the task & 18 & $20,9 \%$ & 24 & $27,9 \%$ & 44 & $51,2 \%$ \\
\hline 10. & Did not belive my ability & 4 & $4,7 \%$ & 14 & $16,3 \%$ & 68 & $79,1 \%$ \\
\hline 11. & Did not interest with the topic given & 5 & $5,8 \%$ & 20 & $23,3 \%$ & 61 & $70,9 \%$ \\
\hline 12. & The task was hard & 21 & $24,4 \%$ & 23 & $26,7 \%$ & 42 & $48,8 \%$ \\
\hline 13. & The task requirement was too high & 22 & $25,6 \%$ & 20 & $23,3 \%$ & 44 & $51,2 \%$ \\
\hline 14. & The ease to copy material from the internet & 26 & $30,2 \%$ & 23 & $26,7 \%$ & 37 & $43 \%$ \\
\hline 15. & There were no checking for plagiarism & 21 & $24,4 \%$ & 19 & $22,1 \%$ & 46 & $53,5 \%$ \\
\hline 16. & Never been caught before & 8 & $9,3 \%$ & 10 & $11,6 \%$ & 68 & $79,1 \%$ \\
\hline
\end{tabular}

The table shows that lack of knowledge of plagiarism $(34,9 \%)$ and lack of time $(34,9 \%)$ were the most reason why the graduate students committed plagiarism. Then, the other reason was followed by the students unintentionally $(31,4 \%)$ and the easiness to find material from the internet $(30,2)$. In contrast, getting a high score $(3,5 \%)$, compete with friends $(3,5 \%)$, did not believe with their ability $(4,7 \%)$ and did not interest with the topic given $(5,8 \%)$ were the rare reason why they committed plagiarism.

However, the result of the questionnaire had a slightly different with the interview result. The follow-up interview also confirms that those reasons were the most reasonable. In addition, they all agreed that there is no plagiarism checking and the easiness to find the material from the internet were also be their main reason for committed plagiarism. The percentage of graduate students' reason why they committed plagiarism can be seen in this figure below.

Figure 2. Percentage of Graduate Students' Reason Why Committed Plagiarism 


\section{The Interview}

In order to get a deeper data about the graduate students knowledge and reason why they committed plagiarism, the writers asked three questions, (1) In your opinion, what is plagiarism? (2) can you tell me some types of plagiarism? and (3)In your opinion, why someone committed plagiarism?. As the writer stated before, there were 12 students had been interviewed. The details of the interviewee can be seen in table 3 .

Table 3. Data of The Interviewee

\begin{tabular}{llll}
\hline No & Initial & Major & Knowledge \\
\hline 1. & AS & Bahasa Indonesia & Bad \\
2. & FK & Bahasa Indonesia & Fair \\
3. & MF & Bahasa Indonesia & Good \\
4. & NL & Bahasa Inggris & Bad \\
5. & BL & Bahasa Inggris & Fair \\
6. & ND & Bahasa Inggris & Good \\
7. & IV & Bahasa Arab & Bad \\
8. & AD & Bahasa Arab & Fair \\
9. & RS & Bahasa Arab & Good \\
10. & ED & Keguruan Bahasa & Bad \\
11. & AP & Keguruan Bahasa & Fair \\
12. & NA & Keguruan Bahasa & Good \\
\hline
\end{tabular}

Firstly, the writer tried to ask the respondents to define plagiarism based on their opinion. Mostly, all of the respondents had the same answer which is plagiarism is imitated others' people work, copying others' work, means stealing others' ideas without citing the source and claimed other's work as own. It can be known through these following answers by several respondents.

(1) Plagiarism is taking others work and claimed it as own without citing the sources. (RS)

(2) Plagiarism is fully taking other work without paraphrasing and it must be more that one sentences. (MF)

(3) I cannot explain about the definition of plagiarism well, but in my opinion, plagiarism can be defined picked others writing and change the writer's name into our name. So, I think that was serious plagiarism. (ND)

Therefore, all of the respondents had the same opinion related to plagiarism's definition that plagiarism was claiming others' work into own. Moreover, the writer asked them to tell some types of plagiarism. They had a different response. Some respondents could state several types of plagiarism, while others could not because they never told by their teacher about it.

(4) Like I stated before, my lecturer ever explained about plagiarism but my lecturer never tells me about types of plagiarism. (IV)

(5) I totally had no idea about types of plagiarism. (NL)

Based on data (9) and (10), it showed that some respondents could not mention types of plagiarism. However, other respondents can state types of plagiarism although only a few of it.

(6) I did not know many types of plagiarism. In my opinion, plagiarism was only copy and paste. (ED).

(7) I think plagiarism can be divided into three, complete plagiarism, semi-plagiarism, and slight plagiarism. (MF)

So, it can be seen from data above that only few of the respondent could state the types of plagiarism. it might be caused by they never told about types of plagiarism. Based on the interview about why the students committed plagiarism, the writer asked one question related to the topic. The writer asked the respondents' opinion about why people committed plagiarism. The respondents had various answers about these questions. Some respondents argued that people committed plagiarism because of laziness, lack of knowledge about plagiarism, lack of time to finished the task and the task was too hard like these following statements.

(8) I am sure everybody has their own reason why they committed plagiarism. In my opinion, sometimes people committed plagiarism because he is lazy. Sometimes the lack of time also is one of the reasons why people committed plagiarism. (AP) 
(9) I think, people committed plagiarism because they did not understand plagiarism well, like.... mmm..., they did not know types of plagiarism, so they might be plagiarized unintentionally. Then, sometimes, the task was too hard, so some people chose to plagiarized for finishing their task. (ND)

Some students added that there was no checking for plagiarism could cause people to committed plagiarism, like this following statement.

(10) In my point of view, there was no checking for plagiarism was the main the reason why people committed plagiarism. (FK)

Others students believed that many people committed plagiarism because of did not interest with the topic and the task requirement was too high.

(11) Sometimes, the task requirement was too high, as a result, sometimes I had to plagiarized. (AS)

(12) When the topic is not interesting, I did not have any motivation to finished the task. So, I would choose plagiarized (AD)

In short, graduate students had various reasons why they committing plagiarism. Related with the questionnaire and the interview, they committed plagiarism because of lack of knowledge and limited time to finished their task.

\section{DISCUSSIONS}

This present study showed an interesting finding in this regard. In general, based on the questionnaire and the interview, the study showed the graduate students knowledge of plagiarism can be classify into three, good, fair and bad. Moreover, the majority had good knowledge of plagiarism. Understandings of plagiarism differ between contexts and individuals (Adam, Anderson, \& Smith, 2017). Mostly, the students who had good knowledge were the students who already taught about plagiarism. Although based on the questionnaire and interview there were no students answered No which means all of them ever taught about plagiarism by their teacher in the class, some of them argued that their teacher did not explain clearly about plagiarism. It might be one of the causes that several students still did not understand plagiarism properly. The role of academic staff is important to inform and guide the students to avoid plagiarism (Permana \& Santosa, 2018). The teacher needs to instruct the students about what plagiarism is, types of plagiarism and how to avoid plagiarism (Elander, Pittam, Lusher, Fox, \& Payne, 2010).

Moreover, some of the students ever read a reading journal or websites about plagiarism, as a consequence, they have a better understanding of plagiarism than students who never read about plagiarism. Related to the student's knowledge about types of plagiarism, most of the students knew several types of plagiarism such as using others idea without citing the source, using others idea and claimed it as own, using others work and claimed it as own and copy paste from the internet without citing the sources. In contrast, some students ensured that using the inaccurate source, paraphrasing paragraph without citing the source, and copying paragraph and only made small changes were types of plagiarism.

However, some Indonesian, Mandarin and Arabic major students did not know that copying directly from other language and translating without paraphrasing as plagiarism. While graduate students in the English major seems more familiar with paraphrasing. Mahmood, Mahmood, Khan, \& et al (2011), Orim, Davies, Borg, \& Al (2013) and Riasati \& Rahimi (2013) stated that the lack of sufficient knowledge of plagiarism concepts increases the chances of students plagiarising. It was worrisome that some of the graduate students still confused about the form of plagiarism. Then, some of the students also did not know that cutting and pasting from various material was a form of plagiarism. Besides, several students also did not know that writing inappropriate sources as one kind of plagiarism. Students were not well aware about referencing errors can be considered as a plagiarism (Gullifer, J. \& Tyson, 2014; Mu, 2010).

Further, the majority of graduate students knew about university policy related to plagiarism. In contrast, they did not know where the regulation stated. Some students argued that they only predicted that every university surely had regulation about plagiarism. Thus, there is a paucity of in-depth analyses of students' understandings of plagiarism and plagiarism policy (Adam, Anderson, \& Smith, 2017).

Therefore, based on the finding, can be concluded that most of the graduate students in Universitas Negeri Malang had a high knowledge related with plagiarism and university policy about plagiarism although some students still uncertain related with both of it. If the students had high knowledge about plagiarism, it can be made them avoiding plagiarism. This study showed that most students came into the university with average skills in research and writing, and it still possible that students can commit plagiarism intentionally or unintentionally (Onuoha \& Ikonne, 2013; Ibegbulam, I. J., \& Eze, 2015). 
Based on the questionnaire, a lack of knowledge was the highest reason why graduate students committed plagiarism. Moreover, the limitation of time also is a common answered by the students. This finding in line with Selemani et al (2018) which found that the most frequent reason for plagiarism is "shortage of time in writing papers". If professors are to reduce plagiarism, the first step is probably to try to have a realistic and practical attitude toward assignments. When the students are overloaded with assignments, or when the assignments are beyond their level, they may have no choice but to resort to plagiarism to be able to cope with the required assignments in due time. This study revealed that one of the reasons why the students committed plagiarism was the internet. The easiness to find several materials make several students intended to plagiarize. Similarly, the finding of this study with Ahmadi (2014) the internet has provided the students with lots of opportunities for cheating, and plagiarism is one of it.

This study also revealed several reasons why graduate committing plagiarism such as laziness and pressure to score good grades(Idiegbeyan-Ose et al, 2016; Kwong et al, 2010; Resurreccion, 2012). From these findings, we conclude that students commit plagiarism intentionally and unintentionally. A study by De Jager \& Brown (2010) categorized students copying from each other as intentional plagiarism whereas copying without citing sources was categorized as unintentional because of students plagiarised due to ignorance or incompetence. Likewise, in this study, we conclude that students who plagiarised because of pressure to beat assignment deadlines, laziness and poor time management did it intentionally whereas those who plagiarised due to lack of good academic writing skills did it unintentionally.

\section{CONCLUSION}

This study shows that students have a conceptual understanding of what constitutes plagiarism, in terms of its definition and forms. According to the study, all students regard plagiarism as a serious academic offense. Graduate students believed that using others work and claimed it as owns and copy paste from the internet without citing the source was a form of plagiarism. Plagiarism is something bad to do. The student's perception through it will affect their activities in writing. Students had to avoid plagiarism.

This study also point out that the various reason why graduate students committing plagiarism. Lack of knowledge, lack of time and unintentionally committed plagiarism were the most three reason why the graduate students committing plagiarism. Students unintentionally committed these forms of plagiarism because they lacked skills in summarizing, paraphrasing and referencing properly. Although they had several reasons why they commit plagiarism, they had to prevent it. Plagiarism sometimes related to moral action. It is one of the academic staff to give more information about plagiarism so that plagiarism can be prevented. Based on the finding, we have suggestions for further researcher. This study was conducted on a small scale of respondents so that this result cannot be generalized. So, the next researcher could conduct research in a bigger scope of the study.

\section{REFERENCES}

Adam, L., Anderson, V., \& Smith, R. S. (2017). “It”s Not Fair': Policy Discourses and Students' Understandings of Plagiarism in a New Zealand university. Higher Education, 74, 17-32.

Ahmadi, A. (2014). Plagiarism in the Academic Context: A study of Iranian EFL Learners. Research Ethics, 10(3), 151-168. https://doi.org/DOI: 10.1177/1747016113488859

Bailey, S. (2011). Academic Writing: A Handbook for International Students. London, New York: Routledge.

Batane, T. (2010). Turning to Turnitin to Fight Plagiarism Among University Students. Educ Technol Soc, 13(2), 1-12.

De Jager K, B. C. (2010). The Tangled Web: Investigating Academics' Views of Plagiarism at the University of Cape Town. Stud High Educ, 35(5), 513-528.

Elander, J., Pittam, G., Lusher, J., Fox, P., \& Payne, N. (2010). Evaluation of an Intervention to Help Students Avoid Unintentional Plagiarism by Improving Their Authorial Identity. Assesment and Evaluation in Higher Education, 35(2), $157-171$.

Ellis, C., Zucker, IM., Randall, D. (2018). The Infernal Business of Contract Cheating: Understanding the Business Processes and Models of Academic Custom Writing Sites. International Journal for Educational Integrity, 14(1), 17-24. Retrieved from https://doi.org/10.1007/s40979-017-0024-3

Gallant, T. B. (2011). Building a Culture of Academic Integrity. USA: Magna Publication White Paper.

Gullifer, J. \& Tyson, G. (2014). Who Has Read the Policy on Plagiarism? Unpacking Students' Understanding of Plagiarism. Studies in Higher Education, 39(7), 1202-1218. https://doi.org/10.1080/03075079.2013.777412

Hornby, A. S. (2010). Oxford Advanced Learner's Dictionary of Current English (8th Editio). Oxford: Oxford University Press.

Ibegbulam, I. J., \& Eze, J. U. (2015). Knowledge, Perception and Attitude of Nigerian Students to Plagiarism: A Case Study. IFLA Journal, 41(2), 120-128. https://doi.org/10.1177/0340035215580278

Idiegbeyan-Ose J, N. C. \& O. I. (2016). Awareness and perception of Plagiarism of Postgraduate Students in Selected Universities in Ogun State, Nigeria. Library Philosophy and Practice, (1), 1-25.

Kwong T, Ng H, M. K. et al. (2010). Students' and Faculty's Perception of Academic Integrity in Hong Kong. Campus-Wide Information Systems, 27(5), 341-355. https://doi.org/10.1108/10650741011087766 
Lei, J., \& Hu, G. (2015). Chinese University EFL Teachers' Perceptions of Plagiarism. Higher Education, 70(3), $551-565$. https://doi.org/10.1007/s10734-014-9855-5

Mahmood S T, Mahmood A, Khan M N, Malik, A. B. (2010). Intellectual property rights: conceptual awareness of research students about plagiarism. Int J Acad Res, 2(6), 193-198.

$\mathrm{Mu}$, C. (2010). "I only Cited some of his Words": The Dilemma of EFL Students and Their Perceptions of Plagiarism in Academic Writing. The Journal of Asia TEFL, 7(4), 103-132.

Onuoha, U., \& Ikonne, C. (2013). Dealing with the Plague of Plagiarism in Nigeria. Journal of Education and Practice, 4(11). Retrieved from www.iiste.org.

Orim, S. M., Davies, J. W., Borg, E., \& Al., E. (2013). Exploring Nigerian Postgraduate Students' Experience of Plagiarism: A Phenomenographic Case Study. International Journal Education Integration, 9(1). http://dx.doi.org/10.21913/IJEI.v9i1.845.

Permana, I. G. Y., \& Santosa, M. H. (2018). ELF Students Perception about Plagiarism. In Language in the Online and Offline World 6: The Fortitude (pp. 128-133).

Razera, D. (2011). Awareness, Attitude and Perception of Plagiarism Among Students and Teachers At Stockholm University. Stockholm University.

Resurreccion, P. F. (2012). The Impact of Faculty, Peers and Integrity Culture in the Academe on Academic Misconduct Among Filipino students: An Empirical Study Based on Social Cognitive Theory. Int J Acad Res Bus Soc Sci, $2(12), 33$.

Riasati, M. J., \& Rahimi, F. (2013). Why do Iranian Postgraduate Students Plagiarize? A Qualitative Investigation. Middle East J Scientific Res, 14(3), 309-317.

Sánchez-Vega F, Villatoro-Tello E, Montes-y Gómez M, V.-, \& Pineda L, R. P. (2013). Determining and Characterizing the Reused Text for Plagiarism Detection. Expert System with Applications, 40(5), 1804-1813.

Sarlauskiene, L \& Linas, S. (2014). Understanding of Plagiarism by the Students in HEIs of Lithuania. Procedia - Social and Behavioral Sciences, 110, 638-646.

Selemani, A., Chawinga, W. D., \& Dube, G. (2018). Why do Postgraduate Students Commit Plagiarism? An Empirical Study. International Journal for Educational Integrity, 14(7), 1-15. Retrieved from https://doi.org/10.1007/s40979-018-0029-6

Sikes, P. (2009). Will the Real Author Come Forward? Questions of Ethics, Plagiarism, Theft and Collusion in Academic Research Writing. International Journal of Research and Method in Education, 3(1), 13-24. https://doi.org/10.1080/17437270902749247 